\title{
Study on human resource allocation efficiency based on DEA analysis
}

\author{
Guannan Bao, Fanlei Zeng, Mingwei Wang* \\ Hebei Women's Vocational College, \\ Shijiazhuang, Hebei 050091
}

China

\begin{abstract}
Received: July 10, 2020. Revised: October 12, 2020. 2nd Revised: November 132020. Accepted: November 15, 2020. Published: November 20, 2020.
\end{abstract}

\begin{abstract}
As a new resource, human resource has attracted wide attention in many social fields. The competition of human resource is the competition of productivity between different enterprises. With the reform and opening up, national economy of China continues to develop rapidly. The sound macro-economy and rapidly development of capital market lead the banking industry to have a good development prospect. Whether the human resource allocation of commercial Banks is effective or not has a great impact on the bank earning. This study aims to further clarify the human resource allocation efficiency of banks to improve the efficiency and realize the improvement of bank profits. In this study, computer software was used to calculate the scale efficiency, pure technical efficiency, the change of scale interval and data envelopment analysis (DEA) efficiency of some selected representative banks according to the DEA model. The analysis showed that the DEA scale of many banks could reach the valid value 1 , and the human resource allocation efficiency was optimized. The pure technical efficiency of some banks was valid value 1 , but the scale efficiency was low and ineffective, which needed to be enlarged appropriately. And the DEA efficiency of some banks was invalid, which was caused by the valid value 1 of the scale efficiency and relatively low pure technical efficiency, and such banks need to make reasonable allocation of human resources.
\end{abstract}

Keywords - data envelopment analysis model, human resources, resource allocation, banking human resources.

\section{INTRODUCTION}

$\mathrm{I}$ $\mathrm{N}$ the process of business development, human resource is the first productivity. Wibisono, Nisafani and Bae believed that only by giving full play to the management resource can the organizational guarantee and human support be provided for the development of enterprises [1]. Human resource allocation is an important part of human resource management. In order to improve work efficiency and achieve the optimal matching of other resources, it is necessary for enterprises to make scientific and reasonable allocation of human resources. In view of the problem of human resource allocation, $\mathrm{Wu}$ et al. [2] put forward a reasonable mechanism of human resources allocation, considered human resource allocation as the formation of multiple teams, and demonstrated the distribution process of Agents and verified that the system could satisfy the demand of tasks through simulation experiments. Luo [3] calculated the membership function of rough entropy according to the historical data of human resources, avoiding the interference of subjective factors. According to the correlation value, the rough entropy value of relevant attributes was calculated and dynamically adjusted, and the maximum entropy result as the target of human resources optimization in the second year was determined. According to different research situations and classifications, Bouajaja et al. [4] studied some major solutions of human resource allocation problems, such as precision, heuristic and super heuristic, and applied them to several fields according to their real life. Ponsteen et al. [5] believed that managing multi-project environment requires different methods from managing individual projects. The main challenge was to allocate scarce human resources to projects in execution, set the most methods setting scope as constraints, and allocate resources to minimize delivery time by optimizing centralization and heuristic algorithms. In order to solve the problem of optimizing the production efficiency of the production line and the distribution of tasks and workshops, which is a famous human resource allocation problem of the distribution and balance of assembly line workers, Bouajaja and Dridi [6] applied ant colony optimization algorithm and studied some parameters of ACO method through numerical simulation. This study studied the human resource allocation of commercial banks by using data envelopment analysis (DEA) model [7, 8], hoping to help commercial banks improve the level of human 
resource allocation, realize resource optimization and improve their competitiveness. The main motivation of studying the human resource allocation efficiency is to improve the efficiency of human resource allocation. The efficiency of human resource allocation will significantly affect the work efficiency of banks, and there are various factors affecting the efficiency of human resource allocation. Compared with the way mentioned above, this study used the DEA model to analyze the human resource allocation of commercial banks. It not only clearly measured the efficiency of human resource allocation in banks but also pointed out the factors that affected the efficiency of human resource allocation. The main contribution of this paper is to provide a better way to measure the human resource allocation of banks and to provide an effective reference for other enterprises to measure their own human resource allocation efficiency.

\section{HUMAN RESOURCE ALLOCATION}

\section{A. Overview of Human Resource Allocation Efficiency}

Human resources refers to the sum of all the human production factors of the internal and external of an organization and plays a role in promoting the goal realization of an organization. Its competitiveness is the core competitiveness of an organization. Its own initiative makes the configuration process relatively complex and difficult, and the subject and object of the configuration can select each other, which requires that the initiative of two parties should be similar and basically adapt to each other. Based on the input-output theory $[9,10]$ proposed by an American economist Wassily Leontief, the human resource allocation efficiency can be used to measure the effective utilization rate of human resources, i.e. the ratio between the input and output of human resources elements. As long as the effective allocation of human resources can be realized, the production efficiency can be improved. In this study, DEA model was used to study the human resource allocation efficiency of commercial banks, hoping to find a method to realize optimization and maximize economic benefits.

\section{B. Introduction to The Related Theory of Human Resources}

(1) Human post adaptation theory $[11,12]$

Human resource management and enterprise strategy interact with each other. When the strategic goals of enterprises change with the internal development stages and the external economic and social changes, the planning of human resources and the post qualification requirements of organizations should also change accordingly.

(2) Pareto optimal theory

Pareto optimal theory was proposed by an Italian economist Pareto [13], which can be briefly summarized as that the welfare of at least one person is better than that of the previous one from the current state of resources allocation to another state of resources allocation without loss of anyone. It also means that resources have reached the optimal allocation state and no further improvement is needed.

\section{DEA MODEL AND MODELING}

\section{A. Introduction to DEA Model}

DEA model is a method to evaluate efficiency based on the concept of relative efficiency, which is applied in many fields currently. Data envelop lines can be obtained by evaluating the relative effectiveness between multiple input and output decision-making units and using mathematical programming model. Decision-making units which fall on the boundary were considered having the most effective input and output combination, and the efficiency value was 1 . But the decision-making units which fail to fall on the boundary were inefficient, and the efficiency value was between 0 and 1 . The applying steps of DEA model is shown in Fig. 1.

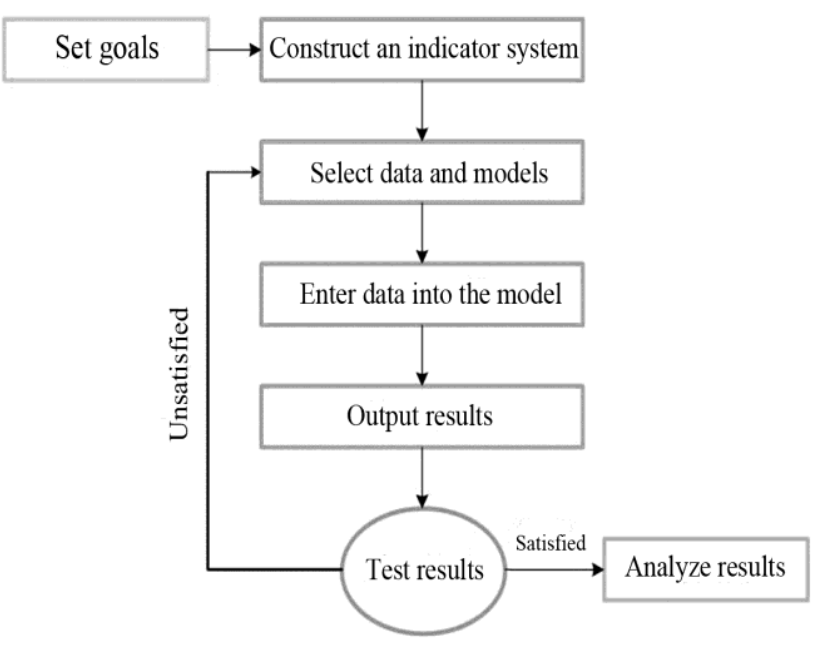

Fig. 1 The applying steps of DEA model

\section{B. Modeling Process}

(1) Basic model: suppose there are $n$ decision-making units, including $\mathrm{w}$ kinds of input elements $\mathrm{x}$ and $\mathrm{z}$ kinds of output elements y , and slack variables $s^{+}$and $s^{-}$were introduced. The two input and output vector were set as $x_{i a}=(a=1,2 \ldots r)\left(x_{i a} \geq 0\right)$ and $y_{i b}=(b=1,2 \ldots e)\left(y_{i b} \geq 0\right)$. The weight variable of $\mathrm{n}$ on a certain indicator is $\lambda_{i}$, and the mathematical expression is established as follows :

the relative efficiency of the decision-making unit $\alpha$ :

$\min \alpha(0<\alpha \leq 1)$

constraint condition: 
$\left\{\begin{array}{l}\text { s.t. } \sum_{\mathrm{i}=1}^{\mathrm{n}} \mathrm{x}_{\mathrm{ia}} \lambda_{i}+s^{-}=\theta x_{o a}(a=1,2 \ldots w) \\ \sum_{\mathrm{i}=1}^{\mathrm{n}} \mathrm{y}_{\mathrm{ib}} \lambda_{i}-s^{+}=y_{o b}(b=1,2, \ldots z)\end{array}\right.$

scope of constraint:

$\lambda \geq 0, s^{+} \geq 0, s^{-} \geq 0$

(2) Charnes, Cooper and Rhodes (CCR) model

The DEA model used in this study aims at multi-objective decision-making problems, especially multi-input and multi-output problems, and is used for evaluating the relative effectiveness of the same departments. Compared with other types of methods for solving multi-objective decision-making problems, the DEA model does not need to set weights in advance, but calculates the optimal weights according to the actual data to reduce the subjective judgment components. Taking the weights of inputs and outputs of the decision-making unit as variables, the evaluation is conducted from the perspective that is the most beneficial to the decision-making unit, avoiding the weight of indexes in the priority sense; it can be assumed that there are different degrees of association between multi-input and multi-output, which does not need to display an expression. CCR model is one kind of DEA model. CCR model is used for studying problems of scale-effective and technology-effective multi-output problems.

The CCR model can be calculated based on the basic model. Suppose that in the case of cone, convexity, invalidity, and minimum axioms, each $\mathrm{p}$ decision-making unit corresponds to the input and output vector combination $\left(x_{n}, y_{n}\right)$; at this moment, the input and output of the decision-making unit are effective and the scale remuneration remains the same. Invest in the reduction ratio $\beta$, and $\beta$ is free, the following expressions were obtained after slack variables $s^{+}$and $s^{-}$were introduced:

the relative efficiency of the decision-making unit $\alpha$ :

$\min \{\alpha\}$

constraint condition:

$$
\left\{\begin{array}{l}
\text { s.t. } \sum_{p=1}^{n} x_{p} \lambda_{p}+s^{-} \leq \alpha x_{p 0} \\
\sum_{p=1}^{n} x_{p} \lambda_{p}-s^{+} \geq y_{p 0}
\end{array}\right.
$$

\section{Data Selection}

Banks are divided into central banks, policy banks, commercial banks, investment banks and the world bank by type. This study studies the most representative commercial banks with more extensive employees. As employees in commercial banks are more extensive, employees that can be selected by this study are more. Limited by the length of the paper, this study only selected some representative commercial banks as the research subjects, including China Merchants Bank, Hua Xia Bank, Bank of Ningbo, Industrial and Commercial Bank of China, Bank of Communications, and China Citic Bank. In the DEA model for the human resource allocation efficiency of commercial banks, and the input and output indicators are shown in Table 1.

Table 1. Indicator system of human resource allocation efficiency

\begin{tabular}{|c|c|c|c|}
\hline \multicolumn{2}{|c|}{ Input indicators } & \multicolumn{2}{|c|}{ Output indicators } \\
\hline \multirow{3}{*}{$\begin{array}{l}\text { Quantity } \\
\text { structure } \\
\text { of human } \\
\text { resources }\end{array}$} & $\begin{array}{c}\text { Total human } \\
\text { resources }\end{array}$ & \multirow[t]{2}{*}{$\begin{array}{l}\text { Growth } \\
\text { ability }\end{array}$} & $\begin{array}{l}\text { Total asset } \\
\text { growth rate }\end{array}$ \\
\hline & $\begin{array}{c}\text { Human } \\
\text { resource } \\
\text { turnover rate }\end{array}$ & & $\begin{array}{l}\text { Net profit } \\
\text { growth rate }\end{array}$ \\
\hline & $\begin{array}{l}\text { Proportion of } \\
\text { staff in } \\
\text { managerial } \\
\text { positions }\end{array}$ & \multirow[t]{4}{*}{ Profitability } & $\begin{array}{l}\text { Return on total } \\
\text { assets }\end{array}$ \\
\hline \multirow{3}{*}{$\begin{array}{c}\text { Quality } \\
\text { structure } \\
\text { of human } \\
\text { resources }\end{array}$} & Average age & & $\begin{array}{l}\text { Cost-revenue } \\
\text { ratio }\end{array}$ \\
\hline & $\begin{array}{c}\text { Educational } \\
\text { level }\end{array}$ & & $\begin{array}{l}\text { Net interest } \\
\text { margin }\end{array}$ \\
\hline & Title structure & & Net spread \\
\hline \multirow{4}{*}{$\begin{array}{l}\text { Cost of } \\
\text { human } \\
\text { resources }\end{array}$} & Staff cost & \multirow{4}{*}{$\begin{array}{c}\text { Financial } \\
\text { innovation } \\
\text { ability }\end{array}$} & $\begin{array}{l}\text { Return on net } \\
\text { assets }\end{array}$ \\
\hline & $\begin{array}{l}\text { Remuneration } \\
\text { payable to staff }\end{array}$ & & $\begin{array}{l}\text { Non-interest } \\
\text { income ratio }\end{array}$ \\
\hline & \multirow[t]{2}{*}{$\begin{array}{c}\text { Average } \\
\text { number of } \\
\text { training days } \\
\text { per year }\end{array}$} & & $\begin{array}{l}\text { Proportion of } \\
\text { net income of } \\
\text { fee and } \\
\text { commission in } \\
\text { operating } \\
\text { income }\end{array}$ \\
\hline & & & $\begin{array}{l}\text { Increase in the } \\
\text { proportion of fee } \\
\text { and commission } \\
\text { income }\end{array}$ \\
\hline
\end{tabular}

According to the China Financial Statistics Yearbook and the annual report data released by commercial banks in 2017, the indicator data of input and output could be found. This article set the number of on-the-job employees, total assets and number of institutions as input indicators, and both the total investment and salary incentive in the theory of human resource were considered [14]. Then, total profit and total deposits were selected as the output indicators. The input and output data of the banking industry are shown in Table 2, and related data of some commercial banks are shown in Table 3.

Table 2. Related input and output data of the banking industry 


\begin{tabular}{|c|c|c|c|c|}
\hline $\begin{array}{c}\text { Staff } \\
\text { number of } \\
\text { the four } \\
\text { major } \\
\text { state-owne } \\
\mathrm{d}\end{array}$ & $\begin{array}{c}\text { Number } \\
\text { of } \\
\text { institutio } \\
\mathrm{ns} \\
\text { (Unit) }\end{array}$ & $\begin{array}{c}\text { Total } \\
\text { assets } \\
\text { (Trillion } \\
\text { yuan) }\end{array}$ & $\begin{array}{c}\text { Total profit } \\
\text { (Trillion } \\
\text { yuan) }\end{array}$ & $\begin{array}{c}\text { Total } \\
\text { deposits } \\
\text { (Trillion } \\
\text { yuan) }\end{array}$ \\
$\begin{array}{c}\text { commerci } \\
\text { al banks } \\
\text { (Ten } \\
\text { thousand } \\
\text { people) }\end{array}$ & & & & \\
\hline 162.3 & 4549 & 252.1 & 161.8 & 169.2 \\
\hline
\end{tabular}

Table 3. Input and output indicator data of some commercial

\begin{tabular}{|c|c|c|c|c|}
\hline $\begin{array}{c}\text { Bank } \\
\text { name }\end{array}$ & $\begin{array}{c}\text { Staff } \\
\text { number } \\
\text { (People) }\end{array}$ & $\begin{array}{c}\text { Total } \\
\text { assets } \\
\text { (Million } \\
\text { yuan) }\end{array}$ & $\begin{array}{c}\text { Total } \\
\text { profit } \\
\text { (Million } \\
\text { yuan) }\end{array}$ & $\begin{array}{c}\text { Total } \\
\text { deposits } \\
\text { (Million } \\
\text { yuan) }\end{array}$ \\
\hline $\begin{array}{c}\text { China } \\
\text { Merchant } \\
\text { s Bank }\end{array}$ & 72530 & 6297638 & 90680 & 4064345 \\
\hline $\begin{array}{c}\text { Huaxia } \\
\text { Bank }\end{array}$ & 42644 & 2508927 & 26253 & 1433907 \\
\hline $\begin{array}{c}\text { Ningbo } \\
\text { Bank }\end{array}$ & 12185 & 1032042 & 10163 & 565253 \\
\hline $\begin{array}{c}\text { Industrial } \\
\text { and }\end{array}$ & 453048 & 26087043 & 361843 & 1922634 \\
$\begin{array}{c}\text { Commerc } \\
\text { ial Bank } \\
\text { of China }\end{array}$ & & & 93265 & 4930345 \\
\hline $\begin{array}{c}\text { Bank Of } \\
\text { Communi } \\
\text { cations }\end{array}$ & 91240 & 9038254 & & \\
\hline $\begin{array}{c}\text { China } \\
\text { Citic } \\
\text { Bank }\end{array}$ & 56724 & 5677691 & 42566 & 3196887 \\
\hline
\end{tabular}

\section{ANALYSIS OF EXPERIMENTAL RESULTS}

\section{A. Analysis of Experimental Data}

Human resource allocation efficiency of some commercial banks could be obtained by using the computer development software MaxDEA [15] and the results are shown in the Table 4.

Table 4. The DEA efficiency of some commercial banks

\begin{tabular}{|c|c|c|c|c|}
\hline $\begin{array}{c}\text { Bank } \\
\text { name }\end{array}$ & $\begin{array}{c}\text { DEA } \\
\text { efficienc } \\
\text { y of a }\end{array}$ & $\begin{array}{c}\text { Scale } \\
\text { efficiency }\end{array}$ & $\begin{array}{c}\text { Pure } \\
\text { technical } \\
\text { efficiency }\end{array}$ & $\begin{array}{c}\text { Scale } \\
\text { interval }\end{array}$ \\
\hline $\begin{array}{c}\text { Huaxia } \\
\text { Bank }\end{array}$ & 0.712 & 0.846 & 0.851 & $\begin{array}{c}\text { Decrease } \\
\text { progressi } \\
\text { vely }\end{array}$ \\
\hline
\end{tabular}

\begin{tabular}{|c|c|c|c|c|}
\hline $\begin{array}{c}\text { China } \\
\text { Merchant } \\
\text { s Bank }\end{array}$ & 1 & 1 & 1 & $\begin{array}{c}\text { Unchang } \\
\text { ed }\end{array}$ \\
\hline $\begin{array}{c}\text { Bank of } \\
\text { Commun } \\
\text { ications }\end{array}$ & 0.875 & 1 & 0.916 & $\begin{array}{c}\text { Decrease } \\
\text { progressi } \\
\text { vely }\end{array}$ \\
\hline $\begin{array}{c}\text { China } \\
\text { Citic } \\
\text { Bank }\end{array}$ & 0.918 & 0.859 & 0.793 & $\begin{array}{c}\text { Decrease } \\
\text { progressi } \\
\text { vely }\end{array}$ \\
\hline $\begin{array}{c}\text { Industrial } \\
\text { and } \\
\text { Commerc } \\
\text { ial Bank } \\
\text { of China }\end{array}$ & 0.894 & 1 & 1 & $\begin{array}{c}\text { Increase } \\
\text { progressi } \\
\text { vely }\end{array}$ \\
\hline $\begin{array}{c}\text { Ningbo } \\
\text { Bank }\end{array}$ & 0.905 & 0.772 & 1 & $\begin{array}{c}\text { Increase } \\
\text { progressi } \\
\text { vely }\end{array}$ \\
\hline Average & 0.884 & 0.913 & 0.927 & $\begin{array}{c}\text { Decrease } \\
\text { progressi } \\
\text { vely }\end{array}$ \\
\hline
\end{tabular}

It was found from Table 4 that the DEA efficiency of China Merchants Bank has reached 1, the scale interval remained unchanged, and the human resource allocation efficiency was effective. In addition, the scale interval of Industrial and Commercial Bank of China and Ningbo Bank was increasing, the pure technical efficiency reached the valid value 1 , and the DEA efficiency was higher than the average. However, although human resource allocation efficiency was high, there were still many problems. The DEA efficiency of other banks had little difference, which fluctuated above and below the average value, 0.884 . The scale efficiency of Bank of Communications has reached the valid value 1 , but the scale interval was decreasing. The pure technical efficiency has not reached the optimal level, and many of them were lower than the average value, 0.927 .

\section{B. Extended Analysis}

For enterprises, the allocation of human resources is a very important factor in enterprise management. As a special enterprise, banks also need to pay attention to the distribution of human resources. When human resources are rich enough, banks can allocate more business to make more profits. However, the increase of human resources will also increase the difficulty of management. If the allocation of human resources is unreasonable, it will lead to waste of resources. For example, a business can obtain $100 \%$ profit only by two people, and after increasing to three people, the profit is still $100 \%$, but it needs the management cost of three people, which leads to the waste of human resources. Therefore, to make full use of human resources, it is necessary to allocate human resources reasonably. The efficiency of human resource allocation is an important index to measure the allocation of human resource. The analytic hierarchy process (AHP) can calculate the allocation efficiency. AHP divides the objects that need to be analyzed into different hierarchies from many aspects and give different hierarchies different weights and evaluation scores to 
get the final score. However, AHP is relatively subjective in weight distribution, and the final score will be affected by the subjective weight distribution. The DEA model used in this study does not need to set the weight of the measurement index in advance, but calculates the optimal weight according to the actual data, reducing the subjective judgment components; taking the weight of different inputs and outputs of the decision-making unit as the variable and evaluating from the perspective that is the most conducive to the decision-making unit avoids the weight of indexes in the sense of priority; it can be assumed that there are different degrees of associations between multi-input and multi-output, but the associate does not need display the expression.

According to the human post adaptation theory and Pareto optimal theory, the resource allocation efficiency of the total number of employees in each bank was not completely effective.

(1) For enterprises with effective DEA efficiency, such as China Merchants Bank, the scale interval remains basically unchanged, and the scale efficiency and pure technical efficiency has also reached the valid value 1. In such commercial banks, the human resource allocation efficiency has been the optimal, and personnel and posts are basically adaptive, which can keep pace with the business operation level. Moreover, they are ahead of other banks in terms of total investment of human resources, optimal allocation and salary assessment and incentive. They only need to improve the level of technological innovation and strengthen management.

(2) For enterprises like Bank of Ningbo whose pure technical efficiency has reached the optimal value 1, and the DEA efficiency was low, but still higher than the average level. Its scale interval was also increasing, but due to its small scale, it may lead to the waste of human resources in the long run, which will reduce the income of banks. Compared with Table 1, it was found that the scientific and reasonable human resource allocation with relatively small scale would result in ineffective scale interval and reduced profit. In this case, the scale should be expanded appropriately, and measures such as campus recruitment should be adopted to improve the operation efficiency.

(3) For the bank like Bank of Communications, the scale efficiency was effective, but the scale interval was decreasing. And the DEA efficiency was low, because the pure technical efficiency was less than 1 . In this case, the staff structure should be optimized to improve the pure technical efficiency by adjusting human post adaptation, such as talent competition and selection of probationary assistant.

(4) Many other joint-stock commercial banks, such as Huaxia bank and China Citic Bank, whose scale interval was decreasing, and the DEA efficiency was less than 1 . The scale efficiency and pure technical efficiency of them were both lower than the average level and invalid, which was evaluated that the human resource allocation efficiency was invalid. In such banking enterprises, the staff structure should be optimized, and human resources should be applied to the most appropriate places according to human post adaptation theory. The pure technical efficiency should be improved by increasing salary incentive, so as to achieve the effective DEA efficiency 1, which is well-matched with scale efficiency and pure technical efficiency.

\section{CONCLUSION}

DEA model was used to select the input and output indicators of the data published by major banks, and corresponding comprehensive technical efficiency, DEA efficiency, scale efficiency and pure technical efficiency were obtained. According to the analysis, the number of commercial banks with effective DEA efficiency was small but exist. It was mainly concentrated in joint-stock commercial banks, and human resource allocation was optimized. If the banking industry is to develop better, banks with the valid value 1 of scale efficiency and ineffective pure technology efficiency must reduce the waste of human resources and optimize human resources scientifically and reasonably. Redundancy can be regarded as an effective means, but changing human post adaptation is the best way. Banks with the valid value 1 of pure technical efficiency and low scale efficiency should expand their scale appropriately and recruit staff to improve their profits. Pure technical efficiency $=1$ means that the current allocation of human resources is within the reasonable range, i.e., there is still a room for the management of human resource, and the low scale efficiency means that the manageable human resources is few. Considering that the management ability of the bank has not reached the limit, it is possible to ensure the technical efficiency not decrease while increasing the scale of the human resource, and the increase of the scale of human resource increases the profit. Other Banks had a low efficiency in human resource allocation, which is basically an invalid value below 1 . Both scale and pure technical level should be adjusted and improved to make the most reasonable use of human resources.

\section{REFERENCES}

[1] A. Wibisono, A. S. Nisafani, H. Bae, et al, "On-the-Fly Performance-Aware Human Resource Allocation in the Business Process Management Systems Environment Using Naïve Bayes," vol. 219, no. 6, pp. 70-80, 2015.

[2] J. Wu, Y. Jiang, and J. Zhu, "Human Resource Allocation Combined with Team Formation," presented at International Conference on Computational Intelligence and Applications, pp. 67-71, 2016.

[3] X. Luo, "Human resource optimization allocation algorithm based on rough entropy," Boletin Tecnico/tech. Bull., vol. 55, no. 7, pp. 165-171, 2017.

[4] S. Bouajaja, and N. Dridi, "A survey on human resource allocation problem and its applications," Oper. Res., pp. 1-31, 2016.

[5] A. Ponsteen, and R. J. Kusters, "Classification of Human- and Automated Resource Allocation Approaches in Multi-Project Management," Proc. Soc. Behav. Sci., vol. 194, pp. 165-173, 2015. 
[6] S. Bouajaja, and N. Dridi, "Research on the optimal parameters of ACO algorithm for a human resource allocation problem," presented at IEEE International Conference on Service Operations and Logistics, and Informatics, pp. 60-65, 2016.

[7] K. Simon-Elorz, F. J. Arcelus, and Z. Melgarejo, "A three-stage DEA-SFA efficiency analysis of labour-owned and mercantile firms," J. Ind. Manag. Optim., vol. 7, no. 3, pp. 573-592, 2017.

[8] $\mathrm{D}$. Wu, "Detecting information technology impact on firm performance using DEA and decision tree," Int. J. Inform. Tech. Manag., vol. 5, no. 2, pp. 162-174, 2017.

[9] D. C. Frechtling, and E. Horváth, "Estimating the multiplier effects of tourism expenditures on a local economy through a regional input-output model," J. Travel Res., vol. 37, no. 4, pp. 324-332, 2016.

[10]L. B. Lave, "Using Input-Output Analysis to Estimate Economy-wide Discharges," Environ. Sci. Technol., vol. 29, no. 9, 2016.

[11]D. T. Kooij, W. M. Van, J. Wilkenloh, et al, "Job Crafting Towards Strengths and Interests: The Effects of a Job Crafting Intervention on Person-Job Fit and the Role of Age," J. Appl. Psychol., vol. 102, no. 6, 2017.

[12]M. Tims, D. Derks, and A. B. Bakker, "Job crafting and its relationships with person-job fit and meaningfulness: A three-wave study," J. Vocat. Behav., vol. 92, pp. 44-53, 2016.

[13]C. Zhu, L. Xu, and E. D. Goodman, "Generalization of Pareto-Optimality for Many-Objective Evolutionary Optimization," IEEE T. Evolut. Comput., vol. 20, no. 2, pp. 299-315, 2016.

[14]M. Sagandykov, and G. Shafikova, "Salary administration as part of employee incentive system at industrial enterprises," vol. 35, pp. 01024, 2017.

[15]L. B. Si, "Regional cooperation efficiency evaluation of equipment manufacturing industry based on DEA method: Empirical analysis of Beijing-Tianjin-Hebei region and Yangtze river delta region," J. Interdiscipl. Math., vol. 20, no. 1, pp. 281-293, 2017.

Guannan Bao received the master's degree of agricultural extension from Hebei Normal University Of Science \& Technology in 2015. She is working in Hebei Women's Vocational College as a lecturer. Her research interest is education.

Fanlei Zeng received the master' degree of engineering from Hebei University of Science \& Technology in 2017. He is working in Hebei Women's Vocational College as an experimenter. His research interest is education.
Mingwei Wang graduated from Hebei Normal University in 2015. She is working in Hebei Women's Vocational College as a lecturer. Her research interest is preschool education.

\section{Contribution of authors}

Guannan Bao analyzed the human resource allocation problem and put forward the DEA model for the problem. Fanlei Zeng selected staffs in commercial banks for data analysis against the human resource allocation problem and discussed the resource allocation efficiency.

Mingwei Wang collected the data of the four commercial banks and studied and verified the test results. 
Creative Commons Attribution License 4.0

(Attribution 4.0 International, CC BY 4.0)

This article is published under the terms of the Creative

Commons Attribution License 4.0

https://creativecommons.org/licenses/by/4.0/deed.en_US 